THE JOURNAL OF THE SOCIETY OF CHEMICAL INDUSTRY, JAPAN.

Vol. XXVIII.

September, 1925.

No. 9.

ABSTRACTS FROM THE ORIGINAL PAPERS.

\title{
STUDIES ON NAPHTHENIC ACIDS. $X$. COMPOSITION OF NAPHTHENIC ACIDS DERIVED FROM NISHIYAMA KEROSENE AND "NEUTRAL" DISTILLATES.
}

By Yoshio Tanaka, Kōgakuhakushi and Shöichirō Nagai, Kögakushi.

(Received March 3, 1925.)

The authors, in continuing their works (Journal of the Society of Chemical Industry, Japan, 1924, 27, 446-455; ibid., I924, 27, 588-594) on the naphthenic acids of Nishiyama (Niigata Prefecture) origin, have isolated the four main constituents from the mixed naphthenic acids obtained from a waste lye produced in the refining of kerosene distillate ( $4 \mathrm{I} .5^{\circ}$ Bé.) of $\mathrm{Ni}$ shiyama crude oil.

The four main constituents isolated are dodecanaphthenic, tridecanaphthenic, tetradecanaphthenic and pentadecanaphthenic acids. The physical properties of these acids and their methyl esters were as follows:

\begin{tabular}{|c|c|c|c|c|c|c|c|c|c|}
\hline \multicolumn{2}{|l|}{ Naphthenic Acid } & \multicolumn{3}{|c|}{ Formula } & \multicolumn{3}{|c|}{ Boiling Poirt } & $d_{4^{\circ}}^{15^{\circ}}$ & $n_{\mathrm{D}}^{15^{\circ}}$ \\
\hline \multicolumn{2}{|c|}{ Dodecanaphthenic acid } & \multicolumn{3}{|c|}{$\mathrm{C}_{12} \mathrm{H}_{22} \mathrm{O}_{2}$} & \multicolumn{3}{|c|}{$168-170^{\circ} \mathrm{C} .(8.9-9.0 \mathrm{~mm})}$. & 0.9712 & r.4697 \\
\hline \multicolumn{2}{|c|}{ Tridecanaphthenic acid } & \multicolumn{3}{|c|}{$\mathrm{C}_{13} \mathrm{H}_{24} \mathrm{O}_{2}$} & $177-179^{\circ} \mathrm{C}$. & $"$ & ) & 0.9736 & 1.4727 \\
\hline \multicolumn{2}{|c|}{ Tetradecanaphthenic acid } & \multicolumn{3}{|c|}{$\mathrm{C}_{14} \mathrm{H}_{26} \mathrm{O}_{2}$} & $186 \div 188^{\circ} \mathrm{C} .($ & $"$ & ) & 0.9762 & I. 4759 \\
\hline Pentadecanaphthenic & acid & \multicolumn{3}{|c|}{$\mathrm{C}_{15} \mathrm{H}_{28} \mathrm{O}_{2}$} & $194-196^{\circ} \mathrm{C} .($ & $"$ & ) & 0.9776 & $\mathbf{r . 4 7 8 4}$ \\
\hline $\begin{array}{l}\text { Formula of } \\
\text { Methyl Esters }\end{array}$ & & \multicolumn{3}{|c|}{ oiling Point } & \multicolumn{3}{|c|}{ Boiling Point } & $d_{4 \circ}^{15 \circ}$ & $n_{\mathrm{D}}^{15^{\circ}}$ \\
\hline $\mathrm{C}_{11} \mathrm{H}_{2} \mathrm{COOCH}_{3}$ & \multicolumn{4}{|c|}{$265-266^{\circ} \mathrm{C} .(760 \mathrm{~mm})}$. & \multicolumn{3}{|c|}{$127-129^{\circ} \mathrm{C} .(8.9-9.0 \mathrm{~mm})}$. & 0.9412 & 1.4579 \\
\hline $\mathrm{C}_{12} \mathrm{H}_{23} \mathrm{COOCH}_{3}$ & 277 & $8^{\circ} \mathrm{C} .($ & , & ) & $13^{6-1} 3^{\circ} \mathrm{C}$. & $"$ & ) & 0.9443 & 1.4612 \\
\hline $\mathrm{C}_{13} \mathrm{H}_{25} \mathrm{COOCH}_{3}$ & 289 & $0^{\circ} \mathrm{C} .($ & , & ) & $145 \cdot 5^{-147.5^{\circ} \mathrm{C} .1}$ & $"$ & ) & 0.9491 & 1.4647 \\
\hline $\mathrm{C}_{14} \mathrm{H}_{27} \mathrm{COOCH}_{3}$ & 300 & $\mathrm{r}^{\circ} \mathrm{C} .($ & ", & ) & I $55^{-1} 57^{\circ}$ C. ( & " & ) & 0.9501 & 1.4672 \\
\hline
\end{tabular}


These naphthenic acids are colourless and odourless oil, and their methyl esters are colourless liquid of fruity aroma.

In the earlier paper (ibid., 1923, 26, 309-316.) the authors Fobtained tridecanaphthenic, tetradecanaphthenic and pentadecanaphthenic acids as the principal constituents of mixed naphthenic acids of Kurokawa origin. It is worthy of remark that the naphthenic acids of Nishiyama origin have the specific gravities lower than those of Kurokawa origin, and that the main constituents of naphthenic acids of both origins are isomeric respectively. The authors obtained also the same constituents from the mixed naphthenic acids derived from the "Neutral" distillate (33.2 Bé.) of Nishiyama origin. It is also suggested that the occurrence of these isomeric forms of naphthenic acids has some significance to the formation of the crude oils, in which these acids are contained.

(Applied Chemistry Department, Engineering Faculty, Tokyo Imperial University, Tokyo, Japan.)

\title{
THERMOCHEMISCHE UNTERSUCHUNGEN DES ERDÖLS. I. MitTeilung.
}

\author{
Von G. Kita, Kōgakuhakushi und R. Abe, Kögakushi.
}

(Eingegangen am 18. Mai 1925)

Das Verhalten des Erdöls gegen Wärme wurde durch „Differential Arrangement “ der Thermoelemente (Robert-Austen, Proc. Mech. Eng:, 1899, 38) untersucht, indem zwei Paare von Thermoelementen in Glasröhren mit bezw. ohne Erdöl eingelegt wurden, dieselbe wieder in Kupferblöckchen eingestellt wurden, um gleichmäsșig im elektrischen Ofen erhitzt zu werden. Während der Erhitzung wurde gereinigte Kohlensäure ins Öl hineingeleitet.

Versuche mit "Socony motor oil (heavy)" in bezw. ohne Gegenwart des Katalysators $\mathrm{AlCl}_{3}$ unter Erhitzung mit verschiedener Geschwindigkeit, d. h. $3^{\circ}, 5^{\circ}, 8^{\circ}$, bezw. $11^{\circ}$ per Minute, wurden, ausgeführt, und die erzielten Resultate sind in zwei Kurvenabbildungen ausgedrückt (Vergl. Abb. im Text).

Aus den Kurven sieht man deutlich, dass die Thermoreaktion des Erdöls nicht nur endothermisch, sondern auch exothermisch ist, und zwar findet sie 
sich bei diesen Beispielen bei Erhitzung mit einer Geschwindigkeit von $3^{\circ}$ per Minute bei $150^{\circ}$, ebenfalls mit wie ohne dem Katalysator. Diese exothermische Reaktion dauert bis $\mathrm{zu} 250^{\circ}$, und nach einer kurzen Pause sich dieselbe Reaktion bei $300^{\circ}$ fort, um wieder endothermisch zu verlaufen. Etwas über $500^{\circ}$ findet man einen steilen Veränderungspunkt.

Die Knickpunkte verschieben sich mit der Geschwindigkeit der Erhitzung, und die Kurvenformen verändern sich enorm bei Gegenwart vom Katalysator.

Die diesbezüglichen chemischen Erklärungen werden folgen.

\section{A METHOD OF PREPARING HIGHLY UNSATURATED ACIDS FROM FISH OILS.}

\section{By Yoshiyuki Toyama, Kögakushi and Tomotarō Tsuchiya.}

(Received May 18, 1925.)

The method of separating highly unsaturated acids from less unsaturated and saturated acids, based on the different solubility of their sodium. soaps in acetone containing water, alcohol or both of them, recently proposed by us, (This Fournal, I925, No. 6, 653) is modified so as to work with the original fish oils instead of the fatty acids.

The accompanying table shows some results obtained in a comparative experiment carried out in the following manner.

About $5 \mathrm{~g}$ of fish oil, accurately weighed, is saponified in a flask with 7.5 c. c. of a caustic soda solution $(25 \mathrm{~g}$ caustic soda is dissolved in $50 \mathrm{c}$. c. of water and 100 c. c. of $95 \%$ alcohol) by boiling for half an hour on a water bath under a reflux condenser. Upon the completion of saponification, the solution is allowed to cool a little and neutralized with an acetic acid solution (glacial acetic acid is diluted with equal volume of water). Denote the number of c. c. of the acetic acid solution required by a. 4.5-a c. $c$. of water and 88 c. c. of acetone are then added. By this operation, soft gelatinous mass of brownish colour separates out conjointly with faintly coloured precipitate of insoluble sodium soaps. . The flask is again refluxed until soft gelatinous mass disappears, whilst faintly coloured precipitate of 
insoluble sodium soaps remains undissolved. Instead of adding acetone at a time, it may be added in two portions. In this case, 4.5-a c. c. of water and 40 c. c. of acetone are added at first. The flask is refluxed until all the precipitates disappear and the solution becomes clear. When the solution is cooled a little, $48 \mathrm{c}$. c. of acetone is gradually added into the solution while the flask is gently rotated. The flask is then placed in ice water for about 2 hours and the solution is filtered through a dry filter paper, the funnel being packed with ice water. $50 \mathrm{c}$. c. of the filtrate at room temperature is pipeted off, the acetone is distilled over, and the residue is decomposed with dilute hydrochloric acid. The liberated acids are taken up with petroleum ether. The petroleum ether solution is distilled over in a tared flask and its residue is weighed; this multiplied by a represents the amount of highly unsaturated acids (acids whose sodium soaps are soluble in the menstruum employed).

Highly Unsaturated Acids.

\begin{tabular}{|c|c|c|c|c|c|}
\hline \multicolumn{3}{|c|}{$\mathrm{A}$} & \multicolumn{3}{|c|}{$B$} \\
\hline & $\begin{array}{l}\text { lodine } \\
\text { value }\end{array}$ & $n_{D}^{20^{\circ}}$ & 1 & $\begin{array}{l}\text { odine } \\
\text { value }\end{array}$ & $n_{D}^{20^{\circ}}$ \\
\hline 15.5 & 275 & $1.483^{2}$ & 15.6 & 275 & 1. 4833 \\
\hline 27.0 & $3^{1} 3$ & 1.4879 & 26.7 & $3^{12}$ & 1. 4877 \\
\hline $42 \cdot 3$ & 349 & 1.4928 & 42.1 & $35^{I}$ & I. $49^{29}$ \\
\hline
\end{tabular}

A. Acetone is added at a time; B. Acetone is added in two portions.

The samples in these experiments are the same with those used in the previous paper.

A comparison of the results of these experiments with those of earlier experiments shows that with a sample like Kasuzame oil having a high content of highly unsaturated acids, the yield of highly unsaturated acids is better when the original oil is treated than when the fatty acids are treated, while the iodine values of highly unsaturated acids lie nearly same in both cases. A further experiment shows that the result of this method depends not only on the composition of menstruum but also on the quantity of menstruum employed. When a lesser quantity of menstruum is used, the yield of highly unsaturated acids decreases, whilst their iodine value rises.

(The Tokyo Imperial Industrial Laboratory, Yoyohata near Tokyo.) 


\section{THE HIGHLY UNSATURATED ACIDS OF SOME SHARK AND RAY LIVER OILS.}

\section{By Yoshiyuki Toyama, Kōgakushi and Tomotarō Tsuchiya.}

(Received May 18, 1925.)

Some kinds of shark liver oils and also ray liver oils with the exc tion of Yamato-torpedo oil (liver oil from Narcacion tokionis) contain of a small amount of unsaponifiable matter. The fatty acids of these . have generally high iodine values and yield a considerable amount of etr. insoluble bromides, indicating the presence of a large amount of hig unsaturated acids. 3 samples of these oils have been treated by means sodium-soap-acetone method recently proposed by us (See preceding pap The highly unsaturated acids obtained by this method were esterified w methyl alcohol and the methyl esters fractionated under diminished pressu

From an examination of each fraction, the following conclusions $h$ been drawn: (I) The fatty acids of lower fractions contain a considera amount of less unsaturated acids besides highly unsaturated acids, while fatty acids of higher fractions consist exclusively of highly unsaturated ac (2) The highly unsaturated acids of the oils examined consist predominar of $\mathrm{C}_{20}$ and $\mathrm{C}_{22}$ acids. $\mathrm{C}_{18}$ acids are present only in a lesser amount. acids may be present in a minute amount. The presense of more hig unsaturated acicls than $\mathrm{C}_{22} \mathrm{H}_{34} \mathrm{O}_{2}$, though in minute amount, in higher $\mathrm{ft}$ tions is conceivable.

Table I. General properties of oils examined.

\begin{tabular}{|c|c|c|c|}
\hline & $\begin{array}{c}\text { Kasuzame oil } \\
\text { Liver oil from } \\
\text { S. japonica } B l k .\end{array}$ & $\left.\begin{array}{c}\text { Nezumizame oil } \\
\text { Liver oil from } \\
L . \text { cormubica } G m l .\end{array}\right)$ & $\begin{array}{c}\text { Tsubakuro-ei oil } \\
\left(\begin{array}{c}\text { Liver oil from } \\
P . j a p o n i c a\end{array}\right)\end{array}$ \\
\hline Sp. gr. $\left(15^{\circ} / 4^{\circ}\right)$ & 0.9333 & 0.9293 & 0.9290 \\
\hline Acid value & $0.6 \mathrm{r}$ & 2.8 & I.I \\
\hline Sap. value & 187.6 & 188.1 & 188.4 \\
\hline Iodine value (WVijs) & 204.6 & 179.9 & 160.8 \\
\hline Refr. index $\left(20^{\circ}\right)$ & 1.4843 & $\mathbf{1} .4825$ & 1.4797 \\
\hline Unsap. matter ( $\%)$ & $\mathbf{1 . 6 9}$ & 2.87 & $\mathbf{I} \cdot 47$ \\
\hline $\begin{array}{l}\text { Ether-insol. bromides } \\
\text { from fatty acids }(\%)\end{array}$ & 63.05 & 56.78 & 56.17 \\
\hline
\end{tabular}


Table II. Highly unsaturated acids obtained by sodium-soap-acetone method.

$\begin{array}{lccc} & \text { Kasuzame oil } & \text { Nezumizame oil } & \text { Tsubakuro-ei oil } \\ \text { Neutr. value } & \mathbf{1 7 7 . 1} & 177.8 & 178.4 \\ \text { Sap. value } & 177.7 & 178.4 & 179.4 \\ \text { Iodine value }(\mathrm{Wijs}) & 360.9 & 368.3 & 334.4 \\ \text { Refr. index }\left(20^{\circ}\right) & \mathbf{1 . 4 9 4 0} & 1.4949 & 1.4906\end{array}$

Highly unsaturated acids in Table II are freed from unsaponifiable matter.

(The Tokyo Imperial Industrial Laboratory, Yoyohata near Tokyo.)

\section{IODINE VALUE OF hIGHLY UNSATURATED ACIDS.}

\section{By Yoshiyuki Toyama, Kōgakushi and Tomotarō Tsuchiya.}

(Received May 19, 1925.)

Parallel determinations of the iodine value of methyl ester of highly unsaturated acids were conducted by well-known five methods- the methods of Hübl, Waller, Wijs, Hanus and Winkler-and recently published two methods-- alcoholic iodine method of Margosches and his co-workers 2 . angew. Chem., I924, 37, 334) and pyridine sulfate dibromide method of Rosenmund and Kuhnhenn (Z. f. Unters. d. Nahr.-u. Genussm., 1923, 46. I 53).

A number of determinations by each method was carried out hy varying the amount of excess of reagent and the period of reaction. The methyl ester used in the experiments (Table I-VII) was obtained from Japanese sardine oil by fractionating metyl ester of a concentrate of highly unsaturated acids prepared by means of scdium-soap-acetone method (See preceding paper). It is a light yellow liquid with boiling range $210-225^{\circ}(5 \mathrm{~m} . \mathrm{m}$. .), Sap. v. 172.2 and Refr. index $\left(20^{\circ}\right) 1.4890$.

The results of experiments are recorded in Table I-VII.

A. Experiments with small excess of reagent.

B. Experiments with moderate excess of reagent.

C. Experiments with large excess of reagent.

Excess of reagent is expressed in persentage to the total amount of reagent employed.

The iodine values marked ( 1 ) and (2) in the case of 24 hours' reaction period in Hübl's meihod (Table I) are calculated respectively by the formulae

$$
\begin{gathered}
\frac{100 F}{M}\left(\frac{b_{0}+b_{t}}{2}-a\right) \text { and } \frac{100 F}{M}\left\{\left(b_{0}-a\right)-\left[\frac{a}{b_{t}}\right]^{\prime}\left(b_{0}-b_{t}\right)\right\}, \\
- \text { I I } 4-
\end{gathered}
$$


where $F$ denotes grs. of iodine equivalent to I c. c. of thiosulfate solution, $M$ grs. of sample taken, $a$ c. c. of thiosulfate solution required for titrating back the excess of reagent in the experiment, $b_{0} c . c$, of thicsulfate solution required for the blank test titrated at the commencement of the experiment, $b_{t}$ c. c. of thiosulfate solution required for the blank test titrated at the end of the experiment. The latter formula has been introduced by S. Schmidt-Nielsen and Aage W. Owe (Chem. Umschau, 1924, 31, 53).

Experiments $A, B_{1}$ and $B_{2}$ in Table VI (Pyridine sulfate dibromide method) were carried out with $\frac{\mathbf{I}}{10} N$ pyridine sulfate dibromide solution, while Experiments $\mathrm{B}_{3}$ and $\mathrm{C}$ in the same table with $\frac{\mathrm{I}}{5} N$ solution.

Regarding the formation of $\mathrm{HI}$ in alcoholic iodine method, a further experiment was made with a sample (methyl ester) prepared from cod liver oil. The results of this experiment are found in Table VIII. The same sample gives an iodine value 328.1 (mean of several determinations) by pyridine sulfate dibiomide method. In Table VIII, HI is calculated in terms of iodine and expressed in persentage to the total amount of iodine consumed.

Table I. Hübl's method

$$
\begin{aligned}
& \begin{array}{c}
\begin{array}{c}
\text { Period of } \\
\text { reaction }
\end{array} \\
\begin{array}{c}
\text { Excess of } \\
\text { reagent }
\end{array}
\end{array} \begin{array}{c}
\text { Iodine } \\
\text { value }
\end{array} \\
& { }_{\mathrm{A}} \int_{24 \mathrm{hrs} .} \quad \begin{array}{rrr}
27.65 & 303.4 \\
6 \mathrm{hrs} . & 2 \mathrm{r} .86 & 325.8 \\
24 & \mathrm{r} 6.33 & 342.8
\end{array} \\
& \text { A } 24 \text { hrs. } \quad \begin{array}{llll} 
& 16.33 & 342.8 \\
& & \text { (I) } 347.5
\end{array} \\
& \text { B }\left\{\begin{array}{r}
2 \text { hr's. } \\
6 \text { hrs. } \\
24 \text { hrs. }
\end{array}\right. \\
& \text { c. }\left\{\begin{array}{r}
2 \text { hrs. } \\
6 \text { hrs. } \\
24 \text { hrs. }
\end{array}\right. \\
& \text { (2) } 35^{2.0} \\
& \begin{array}{ll}
50.25 & 318.5
\end{array} \\
& 46 .{ }^{2} 5 \quad 339.6 \\
& 43.90 \quad 352.7 \\
& \text { (I) } 358.1 \\
& \text { (2) } 361.4 \\
& \begin{array}{l}
73.35 \\
\quad 332.9
\end{array} \\
& \begin{array}{ll}
72.06 & 35^{2.8}
\end{array} \\
& 71.62 \quad 354.7 \\
& \text { (I) } 360.6 \\
& \text { (2) } 360.4
\end{aligned}
$$

\begin{tabular}{|c|c|c|}
\hline $\begin{array}{l}\text { Period of } \\
\text { reaction }\end{array}$ & $\begin{array}{l}\text { Excess of } \\
\text { reagent }\end{array}$ & $\begin{array}{l}\text { Iodine } \\
\text { valce }\end{array}$ \\
\hline Io mins. & 35.20 & 289.8 \\
\hline 30 mins. & 27.63 & 321.9 \\
\hline 2 hrs. & 25.02 & 335.9 \\
\hline 5 hrs. & 21.II & 350.8 \\
\hline
\end{tabular}

Table III. Wijs' method

$$
\begin{aligned}
& \text { Period of } \\
& \text { reaction }
\end{aligned}
$$

$\begin{array}{cc}\begin{array}{c}\text { Excess of } \\ \text { reagent }\end{array} & \begin{array}{c}\text { Iodine } \\ \text { value }\end{array} \\ 22.55 & 351.9 \\ 20.97 & 360.5 \\ 21.67 & 360.3 \\ 19.94 & 364.3\end{array}$

Table II. Waller's method

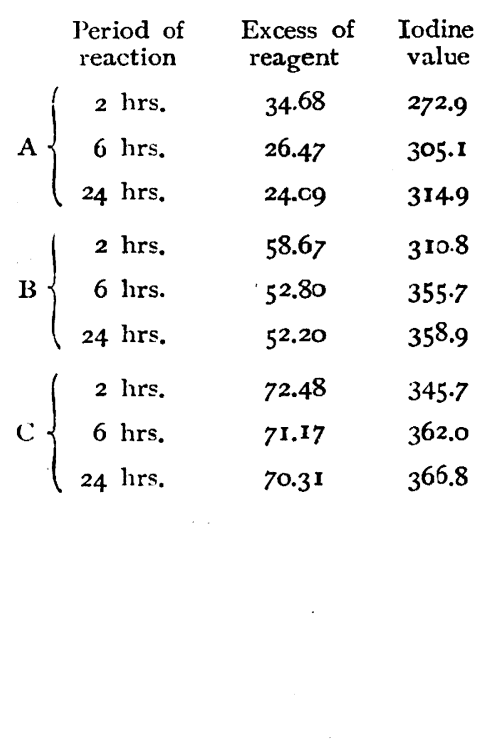

Table IV. Hanus' method 


B $\left\{\begin{array}{rrr}5 \text { mins. } & 47.57 & 358.8 \\ \text { 10 mins. } & 47.40 & 359.9 \\ 20 \text { mins. } & 47.10 & 360.5 \\ \text { 30 mins. } & 47.12 & 360.4 \\ \text { I hr. } & 47.26 & 360.8 \\ 2 \text { hrs. } & 46.93 & 361.2 \\ \text { 15 hrs. } & 45.84 & 366.0 \\ 5 \text { mins. } & 73.14 & 367.6 \\ \text { 10 mins. } & 72.85 & 370.0 \\ 20 \text { mins. } & 72.79 & 372.4 \\ 30 \text { mins. } & 72.78 & 372.5 \\ \text { I hr. } & 72.42 & 373.3 \\ 2 \text { hrs. } & 72.32 & 374.1 \\ 15 \text { hrs. } & 72.67 & 373.7\end{array}\right.$

Table V.

Winkler's method

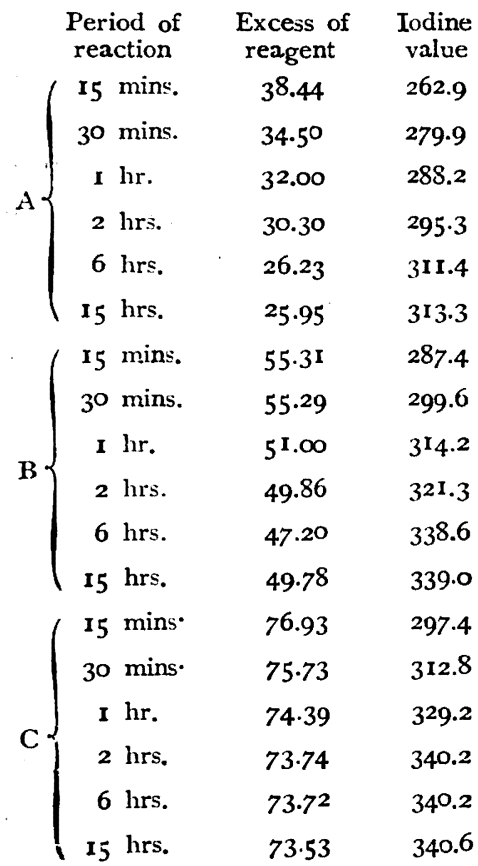

B $\left\{\begin{array}{rrr}5 \text { mins. } & 49.65 & 339.0 \\ \text { 1o mins. } & 49.5^{2} & 340.2 \\ \text { 20 mins. } & 48.48 & 344.5 \\ \text { 30 mins. } & 48.00 & 347.3 \\ \text { I hr. } & 48.24 & 348.9 \\ \text { 2 hrs. } & 48.21 & 348.1 \\ \text { 15 hrs. } & 47.81 & 351.2 \\ 5 \text { mins. } & 74.04 & 349.2 \\ \text { 10 mins. } & 73.80 & 352.8 \\ 20 \text { mins. } & 73.71 & 353.9 \\ 30 \text { mins. } & 73.59 & 354.9 \\ \text { I hr. } & 73.36 & 355.1 \\ 2 \text { hrs. } & 73.50 & 356.1 \\ \text { 15 hrs. } & 73.43 & 356.1\end{array}\right.$

Table VI.

Pyridine sulfate dibromide method

\begin{tabular}{|c|c|c|}
\hline $\begin{array}{l}\text { Period of } \\
\text { reaction }\end{array}$ & $\begin{array}{l}\text { Excess of } \\
\text { reagent }\end{array}$ & $\begin{array}{l}\text { Iodine } \\
\text { value }\end{array}$ \\
\hline 5 mins. & 21.49 & 317.5 \\
\hline ro mins. & 19.82 & 325.6 \\
\hline 30 mins. & $18.4^{6}$ & 330.6 \\
\hline 2 hrs. & I6.75 & 334.8 \\
\hline 5 mins. & $47 \cdot 78$ & 334.9 \\
\hline Io mins. & $47 \cdot 45$ & 336.7 \\
\hline $\mathrm{I} \mathrm{hr}$. & $47 \cdot 42$ & 338.9 \\
\hline 3 lirs. & $47 \cdot c 9$ & 339.2 \\
\hline 5 mins. & 53.63 & 338.5 \\
\hline Io mins. & $54 \cdot 31$ & 338.3 \\
\hline 2 hrs. & 53.95 & 339.6 \\
\hline 3 hrs. & $53 \cdot 25$ & 341.2 \\
\hline 5 mins. & $4^{6.84}$ & $33^{6.0}$ \\
\hline Io mins. & 47.05 & $33^{8.5}$ \\
\hline 30 mins. & 47.07 & $33^{8.6}$ \\
\hline I 2 hrs. & $4^{6.85}$ & 339.0 \\
\hline 5 mirs. & $73 \cdot 59$ & $337 \cdot 9$ \\
\hline Io mins. & 73.64 & $339 \cdot 1$ \\
\hline 30 mins. & $73 \cdot 4 I$ & $339 \cdot 0$ \\
\hline 2 lirs. & 73.63 & $339 \cdot 1$ \\
\hline
\end{tabular}


Table VII.

Alcoholic iodine method

\begin{tabular}{|c|c|c|}
\hline & $\begin{array}{l}\text { Period of } \\
\text { reaction }\end{array}$ & $\begin{array}{l}\text { Excess of } \\
\text { reagent }\end{array}$ \\
\hline & 5 mins. & $33.9^{2}$ \\
\hline & 10 mins. & $3^{1} .89$ \\
\hline & 30 mins. & 29.59 \\
\hline & I hr. & 27.59 \\
\hline & $2 \mathrm{hrs}$ & 26.74 \\
\hline & 5 mins. & 52.98 \\
\hline & ro mins. & $5^{0.4 \mathrm{I}}$ \\
\hline B & 30 mins. & 48.43 \\
\hline & I hr. & 47.00 \\
\hline & $2 \mathrm{hrs}$ & 46.07 \\
\hline & 5 mins. & 72.70 \\
\hline & Io mins. & 70.95 \\
\hline & 30 mins. & 70.08 \\
\hline & I hr. & 70.32 \\
\hline & 2 hrs. & 69.66 \\
\hline
\end{tabular}

Table VIII.

Alcoholic iodine method

$\left(\begin{array}{l}\text { With the sample prepared from } \\ \text { cod liver oil }\end{array}\right)$

Period of Excess of HI Iodine

B $\left\{\begin{array}{llll}5 \text { mins. } & 52.78 & 52.6 \mathrm{I} & 3 \mathrm{I} 3.8 \\ \mathrm{I} \mathrm{hr} . & 48.73 & 57.40 & 340.8\end{array}\right.$

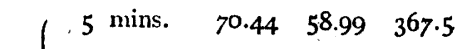

C $\left\{\begin{array}{cccc}30 \text { mins. } & 69.86 & 62.76 & 380.4 \\ \text { I hr. } & 68.69 & 69.57 & 402.7\end{array}\right.$

\section{Conclusions.}

I. Hübl's method. This method requires a long period of reaction. Thus the iodine values in $\mathrm{C}$ become nearly constant but just after 6 hours, while the iodine values in $\mathrm{A}$ and $\mathrm{B}$ rise with increasing the reaction period even after 6 hours. At a reaction period of 24 hours, the values in B and $\mathrm{C}$ are nearly the same. Hence, we can obtain by this method practically constant value, provided a fairly large excess of reagent, say not less than $50 \%$, be employed than the reagent be allowed to act during a period of 24 hours.

2. Waller's method. As in the case of Hübl's method, this method requires a long period of reaction. At a reaction period of 24 hours, the value in $A$ is markedly lower than the values in $B$ and $C$. Even the values in $B$ and $C$ differ somewhat from each other. Thus this method does not yield a constant value within 24 hours.

3. Wijs' method. The absorption of Wijs' solution takes place rapidly. Thus the value at 30 minutes in $A$ and the value at 5 minutes in $B$ differ from the corresponding values at 15 hours only by several units. In $C$, the absorption of the reagent is practically completed within 20 minutes. But 
the value at 20 minutes in $C$ is higher than the values at 15 hours in $A$ and $B$. Hence, the iodine values obtained by this method, carried out under ordinary directions for reaction period, are not quite constant, unless the amount of excess of reagent is limited in a definite range in each determination.

4. Hanus' method. Except in A, the effect of the reaction period and the amount of excess of reagent on the iodine value in this method is essentially similar to that in Wijs' method. However, the effect of reaction period is marked in A. The values obtained by this method are more or less lower than the values obtained by Wijs' method carried out under the same condition of reaction period and excess of reagent.

5. Winkler's method. In this method, the iodine values become constant after 6 hours in B, and after 2 hours in C. It is an advantage of this method over the foregoing methods that this method yields a constant value, independent of the amount of excess of reagent, within comparatively short period of reaction, provided an excess of reagent not less than about $50 \%$ is employed. However, as will be seen in $\mathrm{A}$, this method gives considerably low values even after prolonged period of reaction, if the excess of reagent is not fairly large.

6. Pyridine sulfate dibromide method. Except in A, all values recorded in Table VI are close to one another. Even in $A$, the value reaches 330 after 30 minutes. It will thus be seen that provided a fairly large excess of reagent is used, this method yields rapidly a constant value. It is noticeable that the constant value obtained by this method agrees closely with that obtained by Winkler's method, but is lower than the values obtained by other methods carried out with a sufficient amount of excess of reagent and under ordinary directions for reaction period. We can thoroughly recommend this method so far as the highly unsaturated acids or the oils containing a large amount of highly unsaturated acids are concerned. For such samples, it is preferable to use a fairly large excess of $\mathrm{I} / 5 \mathrm{~N}$ pyridine sulfate dibromide solution and allow the solution in contact with the samples not less than Io minutes.

7. Alcoholic iodine method. The iodine values yielded by this method steadily rise with increasing the reaction period, as the original authors of 
this method have already noted. Even the values at 5 minutes deviate widely from one another according to the amount of exeess of reagent. Thus this method can not be recommended so far as the highly uusaturated acids are concerned. Furthermore, it need be mentioned that HI formed during reaction exceeds $50 \%$ even at a period of 5 minutes, while the iodine value at that point is somewhat lower than the value obtained by pyridine sulfate dibromide method.

(The Tokyo Imperial. Industrial Laboratory, Yoyohata near Tokyo.)

\section{THE COMPOSITION AND FERMENTATION OF A JAPANESE SULPHITE WASTE LIQUOR. \\ By Katsumoto Atsuki, Kōgakuhakushi,}

Yoshitaka Tomoda, Kögakushi and Tatsu Mochizuki, Kögakushi.

(Received May 26, 1925.)

The sulphite waste liquor, produced in a Japanese sulphite mill under a definite condition of cooking, using Abies Sacharinensis and Picea Ajanensis as material, was subjected to the quantitative analysis and fermentation test. The composition of the sulphite waste liquor thus obtained was as follows:

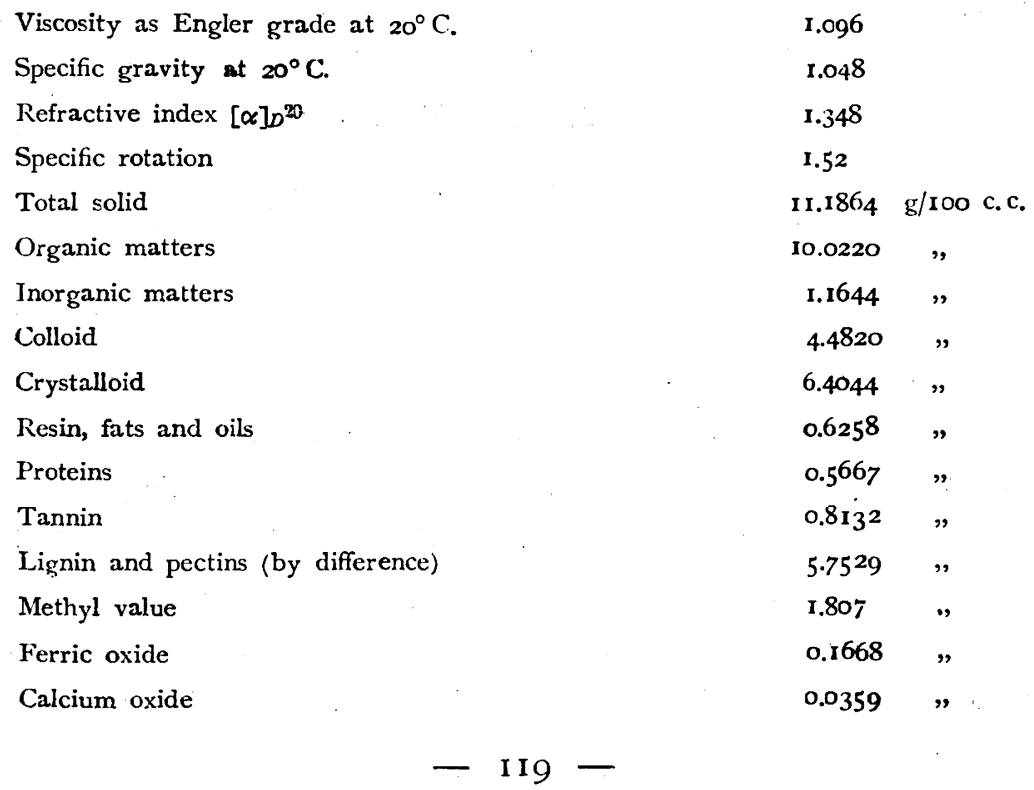




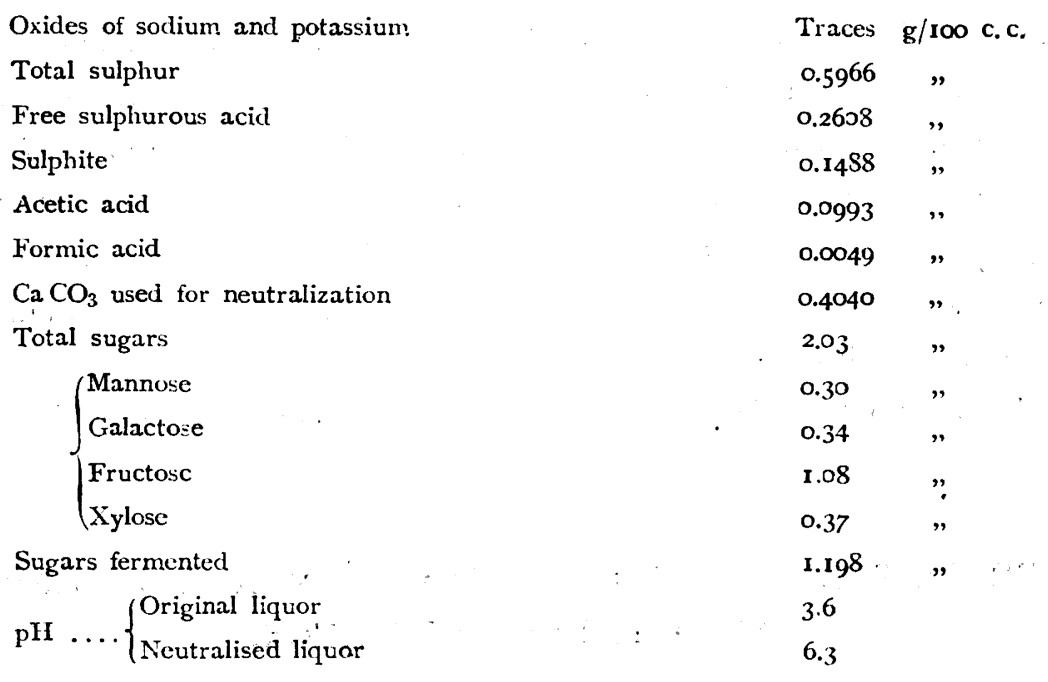

The preliminary experiments upon the fermentation were very hopeful, suggesting that the waste liquor can be used economically as the material for producing alcohol.

Department of Applied Chemistry, Faculty of Engineering, Tokyo Imperial Universily.

\section{SPECTROPHOTOMETRIC STUDIES OF THE LIGHT ABSORPTION OF DYE SOLUTIONS AND DYED FABRICS. \\ (II) THE ACID DYESTUPFS. \\ By Toshio Maki, Kögakushi.}

(Received Junc I, 1925.)

Erythrosine has been used as a representative of the weak acid dyes and orange IV, as a typical acid dyes, the method of the purification of these dyes having been already described in the first report. Various kinds of fibres, which have been also mentioned in the preceding report, were dyed with the above given days, and the dyed fabrics were washed, dried first in the air and finally in a calcium chloride desiccator. The actual weights of the dyestuffs on the fibres were calculated out by estimating the residual dyestuffs in washing water and in dye baths, using Dubosq colori- 
meter, and comparing' with dye solutions of known concentration under the same condition (acidity etc.) as far as possible.

In cases of water solutions, the extinction coefficients $\left(\frac{\log I 0-\log I}{d}\right)$ of the transmitted light were estimated by Nutting spectrophotometer, the concentration of the solutions being without exception $1 / 100,000 \mathrm{~mol}$, With regard to the dyed fabrics, the densities $\left(\log I_{0}-\log I\right)$ of the reflected light were observed using the same spectrophotometer, taking the colourless fabrics as the standard white, while the colourless fabrics themselves had been treated by the same ways as those of the dyed materials, only excluding the dyestuffs.

In these estimations, of course, the zero points of the density scale were frequently and carefully calibrated. The results are shown as density curves in the following figures.

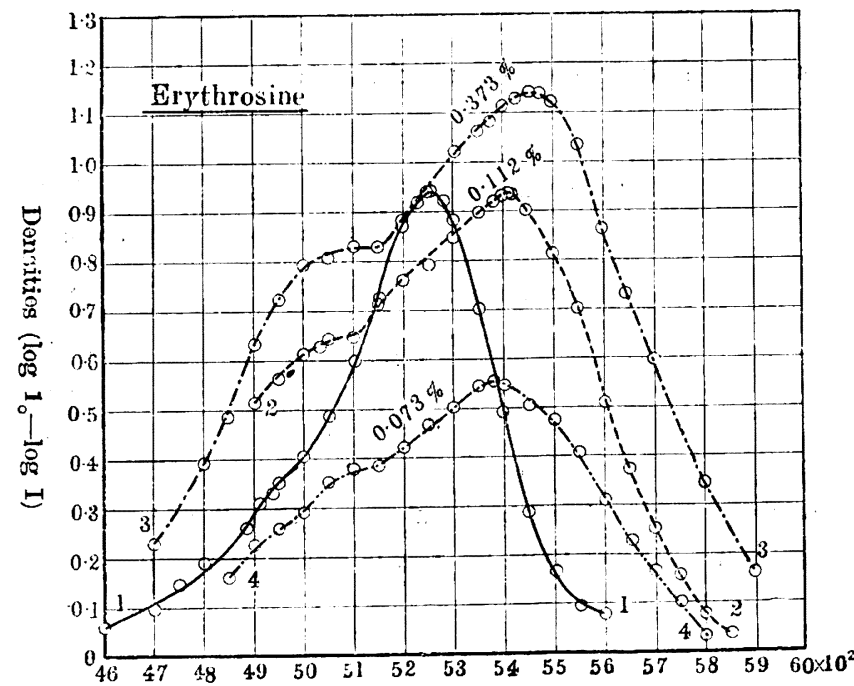

Wave lengths (‥ U.) 


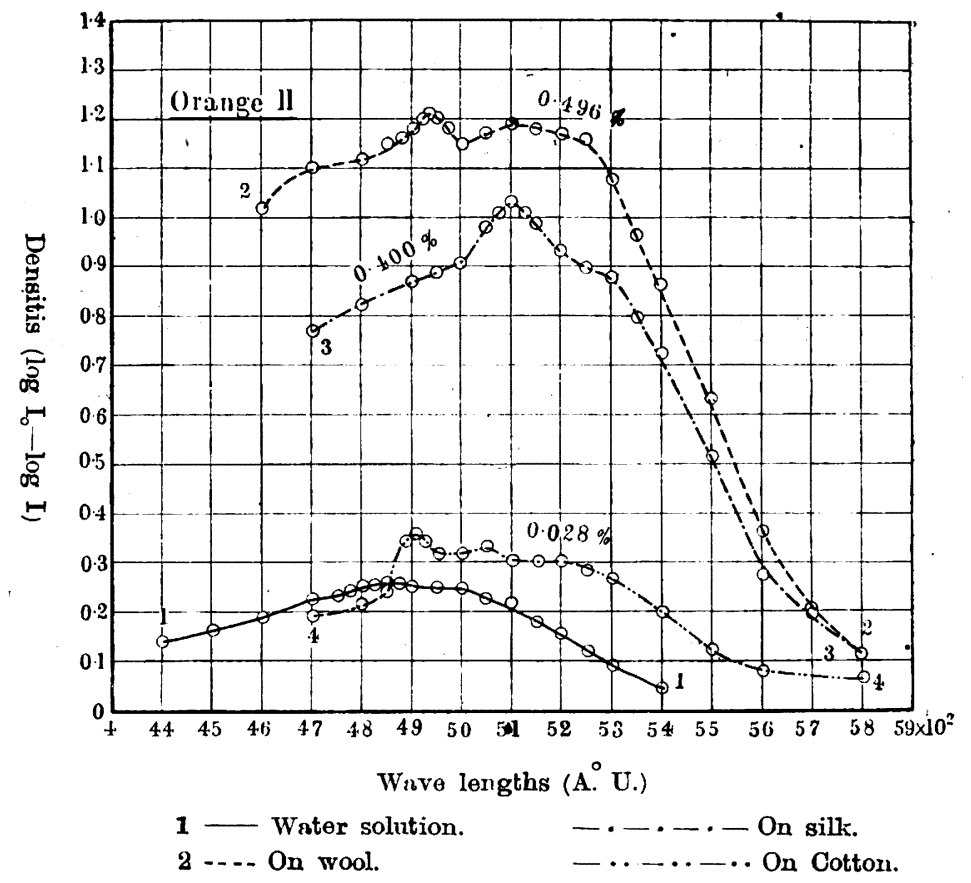

The constants of the points of maximum absorption are as follows : Erythrosine : Concentrations. Wave lengths of $\begin{gathered}\text { Densities of } \\ \text { the point of } \max \text {. the point of } \max \text {. }\end{gathered}$ the point of max. the point of max
absorption

Water solution

$\left(\begin{array}{c}1 / 100000 \mathrm{~mol} \\ \text { Factor } 1.000\end{array}\right)$

$5^{255}$

$0.940(\mathrm{~d}=\mathbf{1}$. $)$

On wool

(\% of dyestuff 0.112 )

5410

0.935

On silk

(\% of dyestuff 0.373 )

5455

1.14

(\% of dyestuff 0.073 )

5380

0.555

(Mere adsorption)

N. B. The $\%$ of the dyestuffs have been calculated as free acid. The water solution contains 10 moles of $\mathrm{KOH}$ for $\mathrm{I}$ mole of free erythrosine.

\section{Orange IV :}

Water solution

$$
\left(\begin{array}{c}
1 / 100,000 \mathrm{~mol} \\
\text { Factor } 1.000
\end{array}\right)
$$

4850

$0.260(d=1$.

On wool

(\% of dyestuff 0.496 )

4935

I.2I

On silk

( $\%$ of dyestuff 0.400 )

$5^{100}$

1.03

On cotton

( $\%$ of dyestuff 0.028 )

4905

0.360

(Mere ad:orption)

N. B. The $\%$ of these dyestuffs have been calculated as sodium salt. 
The density curves are different according to the nature of medium (fibre etc.) and concentration, but they have clearly related tendencies as far as the same dyestuff is concerned. In the cases of the above mentioned acid dyes, colours of fibres are deeper than that of water solution, and among the fibres, silk is the most bathochromic, while cotton is found to be the most hypsochromic. As for the effect of concentration, it will be reported later on.

(Department of Applied Chemistry, Faculty of Engineering, Tokyo Imperial University.)

\section{ON THE DETERMINATION OF URUSHIOL IN JAPANESE LACQUER. (SECOND REPORT).}

By Shigeru Hirano, Kogakushi.

(Received May 29, 1925.)

Besides raw lacquer, there are many varieties of lacquers which are prepared from raw lacquer by special treatments and used for different purposes on lacquer-work.

In these treatments the oxidation of lacquer can not be avoided. The author has proved that the volume of $\mathrm{N} / 4 \mathrm{BaOH}$ solution, required to titrate an alcoholic solution of urushiol by using phenolphthalein as indicator, greatly decreased in such a lacquer which had undergone oxidation without bringing about any marked increase of the weight of urushiol. So that this method for the determination of urushiol can not be used in these cases given above, and also can not be expected to give an accurate result even in raw lacquer undergoing oxidation in a greater or less degree.

\section{DIE NEUE DARSTELLUNGSMETHODE DER AMINOSALICYL- SÄURE UND IHRER HOMOLOGEN.}

Von Takurō Watanabe, Rigakuhakushi.

(E'ng gnngen am 12. Mai 1925)

Es ist shon bekannt, dass Aminosalicylsäure durch Reduzierung von 
Benzol-azo-salicylsäure erhalten werdein kanı. Als Reduzierungsmittel dazu hat man doch bisher (I) $\mathrm{SnCl} \mathrm{Cl}_{2}+\mathrm{HCl}$, (2) Hydrosulfit, (3) $\mathrm{Zn}+\mathrm{NH}_{3}$, und (4) $\mathrm{FeSO}_{4}+\mathrm{Na}_{2} \mathrm{CO}_{3}$ angewendet. Nun hat der Verfasser gefunden, dass Natriumpolysulfid oder Ammoniumsulfid die vorteilhafte wirkung ausübt, wodurch Benzol-azo-salicylsäure und ihre Homologen leicht und zweckmässiger in bzw. Aminosalicylsäure und Deren Homologen übergeführt werden.

Beispiel I : In dem verschlossenen Gefäss versetzt man Benzol-azo-salicylsäure, welche vorher aus I8,6 $\mathrm{g}$ Anilin, $28 \mathrm{~g}$ Salicylsäure dargestellt wurde, mit $70 \mathrm{~g}$ kristallinischem Natriumsulfid, I $2 \mathrm{~g}$ Schwefel, $5 \mathrm{~g}$ Ätznatron, und 50-100 ccm Wasser, und erhitzt auf $80-100^{\circ} \mathrm{C}$ 3-9 Studen unter Umrühren. Nach Abkührung wird das Inhalt abfiltriert und lüsst sich über Nacht stehen, wobei gebildetes Anilin auf der Oberfläche der Lösung ausscheidet und getrennt wird. Wenn die Lösung mit so viel Salzsäure angesäuert, bis sie schwach säuerlisch reagiert, so fällt Aminosalicylsäure samt Schwefel. Dieselben werden abfiltriert, getrocknet, und analisiert. Die Ausbeute beträgt $85 \%$ der Theorie. Um Aminosalicylsäure zu reinigen soll man das Gemisch in heisser, verdünnter Salzsäure lösen und darauf filtrieren. Beim Erkalten scheidet teilweise Salzsäuresaminosalicylsäure aus, und zwar fast vollständig durch Gesättigung mit Chlorwasserstoffgas.

In gleicher Weise kann man p-Toluol-azo-salicylsäure oder p-Xylolazosalicylsäure doch mit geringerer Ausbeute an Aminosalicylsäure reduzieren.

Beispil II : Man erhitzt Benzol-azo-salicylsäure, wie oben beschrieben, mit 48-90 $\mathrm{g}$ wässerigem Ammoniumsulfid $\left(\mathrm{SH}_{2}\right.$ Gehalt, $20 \%$ ) auf $55-60^{\circ} \mathrm{C}$ I-3 Stunden unter starkem Umrühren. Das Reaktionsgemisch wird auf ähnliche Weise, wie in Beispiel I, behandelt. Die Ausbeute betrïgt $79 \%$ der Theorie.

Durch gleiche Bearbeitung können 3 Isomeren der Aminokresotinsäure geliefert werden. 


\title{
UEBER DIE HYDRIERUNG DES $\alpha$-NAPHTHOLS MIT NICKEL- KATALYSATOR UNTER ATMOSPHAERISCHEM DRUCK.
}

\author{
Von Tetsurō Mazume, Kogakushi und Shin-ichirō Iwasaki, Kógakushì.
}

(Eingegangen am 1. Mai 1925)

Die Verfasser haben die Hydrierung des a-Naphthols mit dem Nickelkatalysator unter atmosphaerischem Druck bei $100 \mathrm{C}^{\circ}$ bezw. bei $135-140 \mathrm{C}^{\circ}$ ausgefuert, um festzustellen, ob bei solchen niedrigeren Temperaturen mehr Wasserstoffatome als bei hoeheren in das Naphtholmolekuel cingefuehrt werden und Dekahydronaphthol gebildet wird, wie es sich allgemein erwarten laesst.

Dic Hydrierungsprodukte wurden mehrere Male wiederholt der Hydrierung unterworfen, bis in ihr keine Spur von $\alpha$-Naphthol zu finden war. Auf Analyse enthielten sic zivar ar-Tetrahydro- $\alpha$-naphthol, $\alpha$-Keto-tetrahydronaphthalin und Tetrahydro-naphthalin, aber kein Dekahydronaphthol.

\section{THE RESEARCH OP THE VOLATILIZATION OF IRON FROM SEVERAL WASTE POTTERY MATERIALS BY CHLORINE AT HIGH TEMERATUR (FIRST REPORT).}

\section{By Jirokichi Kumazawa.}

(Received May I, 1925.)

The volatilization of iron from optical glass pots by chlorine at high temperature has already been experienced by J. C. Hostetter, H.S. Roberts and J. B. Ferguson. But the author's purpose was to utilize several waste pottery materials which contain much iron compounds comparatively. The author thought that it is the most clever method to pass the chlorine gas to the pottery bodies without glazing, during firing at $\mathrm{I}, 000^{\circ}-\mathrm{I}, 100^{\circ} \mathrm{C}$, or more.

But yet there are several questions that about the arrangement of the inside space of kiln which is used to place the wares, the treatment of the waste chloride and chlorine, and the economical calculation \&c. 